\title{
Do Iribunal de Contas Como Tribunal de Justiça
}

\author{
JURANDYR COELHO
}

\section{I}

\section{DA JURISDIÇĀO}

Tribunal tem jurisdição sôbre todo o território nacional e exerce essa atribuiçâo sôbre as pessoas e matérias sujeitas à sua competência, a qual abrange todos os responsáveis por dinheiros, valores e material pertencentes à Nação, ou pelos quais esta responda, ainda quando exerçam êles suas funçōes ou residam no exterior, bem como sôbre os herdeiros, fiadores e representantes dos mesmos responsáveis. A jurisdiçāo sôbre as contas públicas é própria e privativa. Intangivel, única e privativa, nesse particular, é a autoridade do Tribunal.

\section{DA COMPETÊNCIA}

Exercendo funçōes previstas na Constituição e na legislação ordinária, compete ao Tribunal de Contas:

$\left.1^{\circ}\right)$ acompanhar e fiscalizar diretamente, ou por Delegaçōes, criadas em lei, a execuçäo do orçamento: e pensôes;

$2^{\circ}$ ) julgar da legalidade dos contratos e das aposentadorias, reformas

3. ) julgar as contas dos responsáveis por dinheiros e outros bens públi$\cos$ e. as dos administradores das entidades autárquicas;

4. $\left.{ }^{\circ}\right)$ eleger seu Presidente e Vice-Presidente;

$\left.5 .^{\circ}\right)$ elaborar o seu Regimento Interno, organizar os seus serviços internos e prover-lhes os cargos na forma da Lei;

$\left.6 .^{\circ}\right)$ propor ao Poder Legislativo a criaçāo ou extinçắo dos cargos e a fixação dos respectivos vencimentos;

$\left.7 .^{\circ}\right)$ dar parecer prévio, no prazo de sessenta dias, a contar da data de sua entrada no Tribunal, sôbre as contas que o Presidente da República deverá prestar anualmente ao Congresso Nacional, ou, quando elas nâo the forem apresentadas até 10 de março, comunicar êsse fato ao Congresso Nacional apresentando, em qualquer dos casos, minucioso relatório do exercícic financeiro encerrado. 


\section{DA COMPOSIÇÃO DO TRIBUNAL DE CONTAS}

O Tribunal compõe-se de nove Ministros (Corpo Deliberativo), nomeados pelo Presidente da República, depois de aprovada a escolha pelo Senado Federal, dentre brasileiros natos, de reputaçăo ilibada e de comprovado saber, especialmente para o desempenho do cargo. Constituem direitos, garantias e prerrogativas do exercício do cargo de Ministro:

a) vitaliciedade;

b) inamovibilidade;

c) aposentadoria, com vencimentos integrais: compulsória, aos 70 anos de idade ou por invalidez comprovada, e facultativa, após trinta anos de serviço público;

d) igualdade de direitos, garantias, prerrogativas e de vencimentos com os Ministros do Tribunal Federal de Recursos;

e) prestaçăo de depoimento mediante designaçăo de data certa;

f) só podem perder o cargo por sentença judicial, por exoneração, a pedido, ou pela incompatibilidade prevista em lei: "nāo poderão ser conjuntamente membros do Tribunal: parentes consanguíneos ou afins na linha ascendente ou descendente e, na linha colateral, até o segundo grau", (artigo 5. ${ }^{\circ}$ Lei n. ${ }^{\circ} 830$, de 23-9-1949);

B) são processados e julgados originàriamente pelo Supremo Tribunal Federal, nos crimes comuns, como nos de responsabilidade.

Por outro lado, sāo êles impedidos de:

a) exercer, ainda quando em disponibilidade, qualquer outra função pública, salvo o magistério secundário ou superior, as funçōes eletivas, as de Ministro de Estado ou cargo federal, a cujo titular sejam conferidas atribuiçōes, honras ou prerrogativas correspondentes às de Ministro de Estado;

b) exercer comissăo remunerada;

c) exercer qualquer profissāo liberal, emprêgo particular, ser comerciante, sócio, gerente ou diretor de sociedades comerciais, salvo acionista de sociedades anônimas ou em comandita por açōes;

d) celebrar contrato com pessoa jurídica de direito público, entidade autárquica, sociedade mista ou emprêsa concessionária de serviço público, salvo quando o contrato obedecer a normas uniformes.

A eleiçāo para Presidente e Vice-Presidente é feita, anualmente, mediante escrutínio secreto realizado na última sessão ordinária do mês de dezembro. Nẫo se considera eleito o que não obtiver a maioria dos votos apurados, caso em que ocorrerá nova votação concorrendo os que alcançaram os dois primeiros lugares no escrutínio anterior, decidindo-se afinal pela antiguidade entre êstes, se nenhum reunir aquela maioria.

Funcionam ainda no Tribunal como serviços autônomos:
a) os Auditores;
b) o Ministério Público;
c) a Secretaria. 
A auditoria é composta de quatro Auditores, selecionados mediante concurso de títulos e provas. O provimento das vagas é feito mediante um critério de alternatividade:

a) metade por concurso de títulos e provas entre funcionários da Secretaria que contarem mais de dez anos de efetivo exercicio no Tribunal e suas Delegaçóes, sem limitação de idade;

b) metade, mediante concurso de títulos e provas, dentre brasileiros natos, bacharéis em Direito, que contarem mais de vinte e cinco e menos de cinqüenta anos de idade.

Os Auditores são substitutos de Ministros - Ministros substitutos - e têm por funçáo relatar os chamados processos de tomada de contas. A substituição é feita observada a ordem de antiguidade, prevalecendo primeiro a nomeaçăo, segundo, a posse e, terceiro, a idade, quando forem da mesma data a nomeação e a posse. A substituição dos Ministros decorrentes de suas faltas ou impedimentos nẩo dá direito à percepçăo de vencimentos integrais senâo quando a substituiçāo fôr superior a trinta dias.

A substituição dos Ministros dar-se-á nos seguintes casos:

a) impedimento ou falta ocasional de Ministros, quando nâo houver "quorum" para a sessáo;

b) afastamento de Ministro por motivo de férias, licença ou decorrente do exercício de função eletiva, de Ministros de Estado ou de cargo federal, a cujo titular sejam conferidas atribuiçōes, honras ou prerrogativas correspondentes às de Ministro de Estado;

c) ou, ainda, quando fôr necessário para completar número a fím de que o Tribunal possa contar com a presença, além do Presidente, de mais cinco Ministros ou seus substitutos.

A convocaçāo cessará desde que:

a) na convocaçáo ocasional compareça o Ministro ou o Auditor anteriormente convocado; Ministro.

b) o Tribunal venha a ter número suficiente pela reassunçẩo de algum

No tocante aos impedimentos tem-se que o Auditor:

a) quando no exercício do cargo de Ministro, aplicam-se-lhe as mesmas incompatibilidades daqueles;

b) nāo pode exercer funçōes e Comissōes da Secretaria, inclusive as de Delegado e Assistente da Delegação;

c) năo pode intervir no julgamento de interêsse próprio ou de parente até segundo grau inclusive, pendente de decisāo do Tribunal ou de suas Delegaçōes;

d) não pode votar nem ser votado nas eleiçōes para Presidente e VicePresidente do Tribunal. 
Quanto aos direitos e garantias observa-se que:

a) têm os mesmos vencimentos atribuidos aos juízes da justiça do Distrito Federal;

b) sòmente perderāo o cargo mediante processo administrativo, por sentença judicial transitada em julgado ou por incompatibilidade prevista em lei decorrente de grau de parentesco.

O Ministério Público é representado por um Procurador, com os requisitos exigidos para a nomeaçāo de Ministro e de um Adjunto, nomeado desde que comprove o exercício por cinco anos, no mínimo, de cargo da magistratura, de Ministério Público ou de advocacia.

A finalidade da existência do Ministério Público junto ao Tribunal é promover, completar a instrução e requerer no interêsse da administração, da Justiça e da Fazenda Pública, sendo obrigatória a sua audiência nos processos de tomada de contas, inclusive os recursos relacionados àqueles e nos de fianças.

Finalmente integra o Tribunal de Contas, a sua Secretaria, e seu quadro de pessoal que se distribui, nāo só pela Secretaria pròpriamente dita como também pelas várias Diretorias de Fiscalizaçāo Financeira, de Tomada de Contas, e Delegaçōes.

\section{DO TRIBUNAL DE CONTAS COMO TRIBUNAL DE JUSTIÇA}

Vista, ràpidamente, a esquematização da organização administrativa do Tribunal, necessário, agora, se faz lançar os olhos para a caracterizaçāo jurídica do órgăo. E problema difícil. £ questăo ainda não pacífica. No entender do autor destas linhas o ponto de vista formal que, tendo em vista única e exclusivamente a lei, o define como órgāo auxiliar do Congresso é errôneo. O que ali se pretende é apenas estigmatizar a origem, o fundamento, a razão de ser das funçōes que recaem sôbre a competência da Côrte de Contas. Náo existe, ali, nada de definitivo para a tepologia da instituiçăo, ao situá-la como órgäo auxiliar do Poder Legislativo.

O que se deve ter em mira, na importância das funçōes confiadas ao Tribunal, é aquela que diz respeito à finalidade para a qual foi criado. Essa finalidade sempre se traduziu em todos os sentido, apenas única e exclusivamente para controlar a aplicaçâo dos dinheiros públicos. $\mathrm{O}$ argumento histó. rico, nesse sentido, é impressionante, e nessa qualidade, a doutrina sempre o considerou como uma forma especial de magistratura. Consulte-se nesse sentido a Exposição de Motivos que antecedeu à sua institucionalizaçăo. A destinação final do Tribunal era e sempre foi a fiscalização dos dinheiros públicos, aplicados de forma direta ou indireta. Era o contrôle dos gastos da Naçäo. Nessa qualidade, procurou-se revesti-lo de qualidades especiais.

E, para que melhor pudesse exercer a sua funçâo, a lei imputou-lhe uma jurisdiçào própria e privativa, única e exclusiva, cujas decisōes, sob a forma de sentença, nāo podem sofrer modificaçăo. Săo terminativas. Inexoráveis, Conclusivas. Isto define a jurisdição contenciosa. Isto define a natureza do 
Tribunal na sua real competência de julgar as contas dos responsáveis por dinheiros e outros bens públicos, como verdadeiro Tribunal de Justiça, de cujas decisōes cabe apenas recurso para o próprio Tribunal.

A competência que a lei the outorgou, nesse sentido, é ampla e até de certo modo criticável, porque incluiu em suas linhas atribuiçōes de caráter meramente normativo. Mas, na realidade, a lei definiu, com precisão, o setor de sua jurisdição, que aprecia a moralidade e a legalidade do manejo dos fundos públicos, com o espírito democrático que deve irmanar todos aquêles que, têm sob sua guarda dinheiros ou outros bens públicos, nẵo se podendo, ninguém - diga-se: ninguém, - beneficiar com qualquer isençấo por mais alta que seja a sua autoridade. O princípio da igualdade, na responsabilidade, consagra-se na Constituição. Não existe exceção. Não há a isenção que seria odiosa nem a exceção, que seria iníqua. Este é o critério justo, esta a apreciaçảo nitidamente democrática no nivelamento de responsabilidade por todos quanto se encontrem nesse nexo causal que deflui da aplicação dos dinheiros da Naçảo.

Nesse sentido, a legislação dispōe que compete ao Tribunal, como Tribunal de Justiça, o que segue:

a) julgar originàriamente ou em grau de recurso e rever as contas de tôdas as repartiçöes, administradores das entidades autárquicas, funcionários e quaisquer responsáveis, incluído o pessoal diplomático e consular no exterior, os quais singular ou coletivamente, houverem recebido, administrado, arrecadado e despendido dinheiros públicos, depósitos de terceiros ou valores e bens de qualquer espécie, inclusive em material, pertencentes à Uniáo, ou pelos quais esta seja responsável, ou estejam êles sob sua guarda, bem assim dos que as deveram prestar e responder pela perda, extravio, subtraçâo ou estrago de valores, bens e material da República ou de que devam dar conta seja qual fôr o Ministério ou órgăo da administraçăo pública a que pertençam $\mathrm{em}$ virtude de responsabilidade por contrato, comissắo ou adiantamento;

b) impor multas e suspender os responsáveis remissos ou omissos na entrega de livros e documentos de sua gestão, ou relativos, a adiantamentos recebidos que não acudirem à prestaçăo de contas nos prazos fixados nas leis e nos regulamentos, ou quando, não havendo tais prazos, forem intimados para êsse fim, independente da açăo dos chefes das repartiçốes que tenham de proceder inicialmente a tomada de contas dos responsáveis sob e sua jurisdição;

c) ordenar a prisáo dos responsáveis que, com alcance julgado em sentença definitiva do Tribunal ou intimados para dizerem sôbre o alcance verificado em processo corrente de tomada de contas, procurarem ausentar-se furtivamente ou abandonarem a função, o emprêgo, comissão ou serviço de que se acharem encarregados ou que houverem tomado sob empreitada. Essa prisāo nāo poderá exceder de três meses. Findo êsse prazo, os documentos que servirem de base à decretaçāo da medida coercitiva, serāo remetidos ao Procurador Geral da República para a instauraçäo do respectivo processo criminal. Essa competência conferida ao Tribunal não prejudica a do Govêrno e seus agentes, na forma da segunda parte do artigo 14 da Lei n. ${ }^{\circ} 221$, 
de 20 de novembro de 1894, para ordenar imediatamente a detençấo do responsável alcançado, até que o Tribunal delibere sôbre êste, sempre que assim - exigir a segurança da Fazenda Nacional;

d) julgar da legalidade da prisāo decretada pelas autoridades fiscais competentes;

e) fixar à revelia o débito dos responsáveis que em tempo não houverem apresentado as suas contas nem devolvido os livros e documentos de sua gestão;

f) ordenar o seqüestro dos bens dos responsáveis ou seus fiadores em quantidade suficiente para segurança da Fazenda;

B) mandar expedir quitaçăo aos responsáveis correntes em suas contas;

h) autorizar a restituiçāo das cauçōes dos responsáveis, quando constituidas por hipotecas e as dos contratantes, provada a execução ou rescisăo legal do contrato;

i) resolver sôbre o levantamento dos seqüestros oriundos de sentença proferidas pelo mesmo Tribunal e ordenar a liberaçâo dos bens seqüestrados e sua respectiva entrega;

j) apreciar, conforme as provas oferecidas, os casos de fôrça maior alegados pelos responsáveis como escusa do extravio dos dinheiros públicos e valores, a cargo dos incriminados, para o fim de ordenar o trancamento das contas, quando por tal motivo, se tornarem iliquidáveis;

k) julgar os embargos opostos às sentenças proferidas pelo Tribunal e a revisão do processo de tomada de contas, em razăo de recurso da parte ou do representante do Ministério Público;

1) expedir instruçōes às repartiçōes federais e entidades autárquicas para levantamento das contas e organizaçāo de processos de tomada de contas aos responsáveis, antes de serem submetidos a julgamento do Tribunal;

$m$ ) impor multa de até $50 \%$ dos vencimentos mensais aos chefes das repartiçōes e inclusive aos administradores das entidades autárquicas, se fôr o caso, que nâo remeterem as contas ou por qualquer motivo deixarem de cumprir as diligências nos prazos fixados pelo Tribunal.

\section{II}

\section{DA RESPONSABILIDADE POR DINHEIROS E OUTROS BENS PÚBLICOS}

O critério predominante, para a fixaçăo da responsabilidade frente ao Tribunal, decorre do exercício de determinadas funçōes que envolvem a custódia de bens ou dinheiros da Naçăo e năo da categoria funcional de servidor público, eis que hipóteses há em que näo existe essa qualidade, e, nem por isso, se rompe a juriscição do Tribunal de Contas. Especificando aquêles jurisdicionados, tem-se que estão sujeitos à prestação de contas:

a) o gestor dos dinheiros públicos e todos quanto houverem arrecadado, despendido, recebido depósito de terceiros ou tenham sob sua guarda e administraçâo, dinheiros, valores e bens da Uniẩo; 
b) todos os servidores públicos civis ou militares ou qualquer outra pessoa ou entidade estipendiados pelos cofres públicos ou não, que derem causa à perda, extravio ou estrago de valores ou de material da Uniâo ou, pelos quais seja esta responsável;

c) os que se obrigarem por contratos de empreitada ou fornecimento c os que receberam dinheiro por antecipaçăo ou adiantamento;

d) os administradores das entidades autárquicas.

\section{DA RESPONSABILIDADE DOS MINISTROS DE ESTADO EM MATÉRIA DE TOMADA DE CONTAS}

Em face do texto acima, é lícito indagar se os Ministros de Estado estão sujeitos de contas. $\mathrm{Na}$ verdade, o problema não apresenta laivos de unidade de ponto de vista, mas a verdade é que nāo existem razōes para que se propugne pela irresponsabilidade daquelas autoridades, por isto mesmo que essa questão não é encarada em relação aos seus aspectos políticos, cuja apreciação não é permitida ao Tribunal. No exercício de julgar da legalidade da aplicação dos dinheiros públicos está implícita a retirada total de qualquer imputaçāo de ordem política nas consequêencias de seus julgamentos. Mas êste fato năo retira ao Tribunal de Contas competência para conhecer da prestação de contas dos Ministros de Estado, definindo-Ihes a situação jurídica, decorrente da aplicaçāo dos dinheiros da Nação. Essa responsabilidade, é evidente, năo se identifica de forma alguma com a responsabilidade politica, que pode trazer como consequência própria a destruiçảo do cargo. A responsabilidade perante o Tribunal de Contas não diz respeito ao Ministro, como tal, mas sim, ao administrador responsável, submetido à função judicante do Tribunal $\mathrm{e}$ às suas sançōes.

Essa diversidade na apreciação de problema impóe-se como regra exigida pelo bom senso, e, sobretudo, pelo empenho do fortalecimento da moralidade administrativa, que se sente atingida por um critério de pura discricionalidade, de onde uma isençăo que, longe de ter a sua razăo de ser, se torna uma medida inexplicável. Mais ainda. Se essa impunidade, no dizer de alguns, existe, os critérios legislativos, que a consagraram hoje, já nâo mais podem substituir. Ao definir o campo de jurisdiçäo, a atual Constituiçăo estabeleceu a competência do Tribunal para o julgamento dos responsáveis por dinheiros e outros bens públicos. Não abriu nenhuma exceçâo, e, se exceção anteriormente houvesse (artigo $\mathbf{8 7 6}$ do Regulamento Geral de Contabilidade Pública) não mais poderiam prevalecer. Mais ainda. Como se observou linhas atrás, ao se especificarem os jurisdicionados do Tribunal, verificou-se que pouco importa a qualidade funcional do responsável. Năo existe, dentro da Constituição e perante a lei, isençāo alguma. Pelo contrário, o que ali se reafirma é a responsabilidade que năo morre com o cargo, nem se extingue com a própria vida. Onde existir a guarda, onde existir o manejo, a aplicaçăo de dinheiros públicos, aí existe a competência constitucional do Tribunal, numa afirmaçāo sábia de que a moralidade administrativa nāo se pode beneficiar de uma isenção que a lei inquina, a moral repele, a justiça condena e o bom senso profliga. 


\section{DOS ADIANTAMENTOS}

Os adiantamentos constituem uma forma específica de movimentaçäo de créditos que, mediante a ocorrência de determinadas circunstâncias, não registradas prèviamente pelo Tribunal de Contas, isto é, antes realizada a despesa, e, posteriormente, são comprovados perante o mesmo Tribunal.

São condiçōes de tempo, de local, de espécie, de destinação e de competência que delimitam a questão da utilizaçăo de créditos orçamentários, sob esta modalidade. que:

Já o artigo 288 do Regulamento de Contabilidade Pública estipulava

"Para serem atendidas, as ordens de adiantamento deverão conter:

a) o exercício a que se refere a despesa; pesa:

b) a verba, consignaçāo e subconsignação por onde deve correr a des-

c) o cargo, repartição e nome do funcionário a que deve ser feito o adientamento;

d) a soma a adiantar, em algarismos e por extenso.

Mais modernamente o artigo 51 da Lei $n^{\circ} 830-49$ indica as condiçōes preliminares ao registro do adiantamento.

Sâo condiçōes que devem constar da solicitaçăo do adiantamento:

a) dispositivo legal em que se baseia a autorizaçăo do Presidente;

b) o nome e o cargo ou função do responsável;

c) a importância a ser entregue e a finalidade a que se destina;

d) a clotaçáo orçamentária ou o crédito por onde será classificada a despesa;

e) o prazo de aplicaçăo.

Ao ser examinada a solicitaçăo em causa, o Tribunal, por ocasiáo do registro, verificará as circunstâncias que condicionam a utilização de tais recursos:

a) pagamentos de despesas extraordinárias e urgente que năo permitam delongas na sua realização;

b) pagamento de despesas que tenham de ser efetuadas em lugar distante de qualquer estaçăo pagadora ou no exterior;

c) pagamento de despesas com a segurança pública, quando declarado o estado de sítio;

d) despesas com a alimentação em estabelecimentos militares, de Essistência, educação e penitenciária, quando as circunstâncias não permitirem o regime comum de fornecimento, inclusive a alimentação dos presos do Departamento Federal de Segurança Pública;

e) de despesas normais nos navios de guerra e nos serviços militares que o exigirem, a juizo do Presidente da República; 
f) de despesas com combustiveis e matérias primas para oficinas e serviços industriais do Estado se as circunstâncias assim o exigirem, a juizo do Presidente da República;

B) de despesas miúdas de pronto pagamento;

h) aquisiçăo de livros, revistas, publicaçôes especializadas, destinadas a bibliotecas ou coleçổes;

i) em casos excepcionais, quando autorizado pelo Presidente da República ou em virtude de expressa disposiçāo de lei;

j) aquísição de objetos históricos, obras de arte, etc, destinadas a coleções, mediante prévia autorização do Presidente da República.

No tocante à concessão dos adiantamentos há que se acentuar que, dentro da própria autoridade executiva, não há nenhum critério para perfeita avaliaçäo an solicitação. As Circulares que têm sido baixadas, nesse sentido, procuram disciplinar o problema, mas a verdade é que, adiantamento solicitado é adiantamento concedido com o beneplácito da autoridade. E perfeito o regime da irresponsabilidade nesse setor. A funcionários que mal podem arcar com a responsabilidade de um nivel de vida dentro dos seus próprios vencimentos, se lança a onerosas cargas de milhares e até milhōez de cruzeiros, num flagrante atestado de incúria administrativa. Tendo um adiantamento prazo fatal de aplicação, dentro de sessenta dias, a contar do seu recebimento, nada obsta que recebido o quantitativo em 29 de dezembro, com êle sejam pagas obras vultosas que jamais terminam em dois dias. $\mathrm{E}$ as denominadas despesas miúdas de pronto pagamento, que tăo fàcilmente se prestam a êsse regime, sāo, em grande número, comprovadas mediante um relacionamento extenso de quantias năo superiores a $\mathrm{CrS} 10,00$, sem qualquer comprovante, usando-se para isso, de um dispositivo que, tendo em mira a exceção, se tornou aplicável quotidianamente. $\mathrm{E}$ dito relacionamento alcança até mesmo a casa das centenas de milhares de cruzeiros. Eis aí o regime do adiantamento mal compreendido, que degenera na irresponsabilidade. Porque a verdade é que os adiantamentos são necessários, mas imperioso é que seja criada uma mentalidade na qual se incuta a assertiva de que um regime de maior liberdade deve corresponder a uma ordem de maior responsabilidade, de tal forma que não se desvirtue a finalidade daquele sistema, que é propiciar uma maior liberdade na aplicaçăo dos créditos orçamentários, liberdade assegurada pela lei e dentro da lei.

Concedido o adiantamento, o responsável terá o prazo de sessenta días para aplicá-lo, salvo se a lei estipular prazo maior e trinta dins para comprová-lo perante o Tribunal, prorrogável por mais trinta pelo Ministro ou autoridade do órgäo diretamente subordinado à Presidência da República, caso seja aplicado nos Estados e Territórios. A năo comprovação dentro daquele prazo, salvo motivo de fôrça maior, importa na multa de $1 \%$ sôbre o total do adiantamento até a entrega da conta e restituiçăo do saldo.

Estando em condiçōes de ser julgado, será submetido à consideraçăo do Tribunal que dará baixa na responsabilidade do servidor que recebeu o ndiantamento, ou entäo mandará, se fồ o caso, sejam apresentadas razōes de defesa. Apresentadas estas, se forem aceitas, proceder-se-á como no ítem 
anterior. Caso contrário, serâo "glosadas" as despesas consideradas irregulares. Dessa decisāo, o responsável poderá interpor, dentro de trinta dias, pedido de reconsideraçāo. Mantida a decisão será a mesma comunicada ao titular do Ministério, Presidente de Departamento, Conselho ou Comissão onde servir o - funcionário, a fim de que se torne efetiva a decisăo. Se, escoado o prazo, o responsável nāo houver recolhido a importância, nem recorrido, a Presidência do Tribunal dará conhecimento à autoridade competente para que proceda como de direito.

Se as contas não forem apresentadas até o fim do exercício seguinte ao em que foi concedido o adiantamento, o responsável será considerado em alcance e contra êle se promoverá o executivo fiscal, não sem que antes se proceda ao levantamento de suas contas.

Se o adiantamento der entrada fora do prazo e houver alguma infraçăo, o processo será instruído como adiantamento, não sendo transformado em tomada de contas.

\section{III}

DO LEVANTAMENTO DAS CONTAS DOS RESPONSÁVEIS POR DINHEIROS E OUTROS BENS PÚBLICOS

O Tribunal de Contas não organiza tomada de contas. Nẫo é o órgăo levantador de contas. No exercício de uma função de caráter normativo êle pode expedir instruçōes às repartiçōes federais e entidades autárquicas, para efeito de levantamento das contas e organização dos processos antes de serem submetidas a julgamento. O levantamento das contas compete, de modo geral, às repartiçōes de contabilidade ou de orçamento, e pode ser feito:

$\left.1^{\circ}\right)$ anualmente, após o encerramento do exercício;

$\left.2 .^{\circ}\right)$ diàriamente: tomadas dia a dia, como, por exemplo, nos processos dos agentes de estrada, em que fica dispensada conta corrente, desde que não haja operações que a justifiquem, sendo imprescindivel, porém, o relatório do tomador de contas, onde se mencionará também a observância do sistema de prestação de contas e de não haver sido apurada responsabilidade contra o responsável;

$\left.3 .^{\circ}\right)$ quando o responsável deixar o cargo, por motivo de dispensa ou na história de falecimento;

$\left.4 .^{\circ}\right)$ quando se verifica desfalque ou desvio de bens da União.

Nessas duas últimas hipóteses o levantamento das contas será iniciado de imediato e terminado em trinta dias.

Além disso, pode o próprio responsável solicitar o levantamento das contas, quando elas năo foram tomadas no seu devido tempo, caso em que a solicitará da autoridade competente, mediante requerimento em que conte: o cargo;

a) data da nomeação, posse, tempo de exercício e dia em que deixou

b) o valor, espécie, natureza da caução prestada, nome de quem a prestou e se foi ou năo aprovada pelo Tribunal de Contas, se fôr o caso; 
c) o motivo pelo qual não foi em tempo próprio levantada a conta.

A finalidade do levantamento ou da tomada de contas é conhecer e corrigir os abusos e irregularidades, prevenir as insolvabilidades, promover o recolhimento dos dinheiros públicos e velar por que os impostos, direitos e taxas fiscais sejam bem arrecadados e aplicados.

A tomada de contas define a situação juridica do responsável perante a Fazenda Pública, e a exoneração dessa responsabilidade, por motivo de falta, deterioração ou diminuição de bens públicos, por caso fortuito, fôrça maior ou natural perecimento, sòmente será admitida mediante prova rigorosa do fato, de que resulte a convicção de inimputabilidade do agente, por dolo ou culpa, mesmo leve, oriunda de negligência ou descuido, em usar dos meios adequados no recebimento, guarda, conserva ou entrega dos bens a êle confiados, como na escrituraçāo regular.

A tomada de contas varia, segundo a natureza das contas a serem tomadas. Assim, por exemplo, as contas dos exatores baseiam-se na tomada mensal das contas pela liquidação dos balancetes mensais, à vista dos documentos de receita e despesa, dos têrmos de balanço que os acompanham e pelos documentos lançados no livro de contas correntes dos responsáveis; em outra hipótese as contas dos almoxarifes e guardas de material têm por base os inventários anuais dos bens sob sua guarda, com as alteraçōes e transformaçōes havidas no correr do exercício; na dos coletores e escrivães, é peça indispensável um quadro demonstrativo contendo as percentagens a que tinham direito os saldos credor e devedor e a renda líquida apurada durante o exercício.

Pelo nāo levantamento das contas ficam as autoridades, a que competirem tal missão, sujeitas à multa imposta pelo Tribunal que poderá alcançar até $50 \%$ dos vencimentos mensais, além das penas disciplinares cabíveis na espécie. O levantamento das contas é feito pelo tomador de contas ou por uma Comissão adrede nomeada para tal fim. Qualquer que seja a forma devem as suas autoridades apresentar um Relatório.

\section{DO RELATÓRIO DO TOMADOR DE CONTAS: ELEMENTOS}

Os elementos que constituem o Relatório do Tomador de Contas são os seguintes:

a) data da nomeação, posse e tempo de exercício; quando foì exonerado e quando deixou o exercício do cargo;

b) o valor, espécie e natureza da caução prestada, inclusive se foi ou năo aprovada pelo Tribunal;

c) importância dos saldos a favor da Fazenda Nacional e sua proveniência;

d) importância dos saldos a favor do exator e se êstes se acham ou năo prescritos; sável;

e) a importância do sêlo de nomeaçăo e sôbre vencimentos do respon- 
f) se houve pagamentos de despesa, com ou sem ordem escrita do ordenador e se houve ou não protesto ou impugnação por parte do responsável;

B) quais as irregularidades havidas nos documentos e na escrituraçăo do responsável;

h) apreciação da defesa do responsável, se houver;

i) apreciação sôbre a situação jurídica do responsável.

\section{DA ORDEM DE ATUAÇÃO DOS PROCESSOS}

A ordem de autuação das peças do processo é a seguinte:

a) peça que deu motivo à tomada de contas, se houver;

b) conta corrente do exercício;

c) conta corrente de fusão;

d) contas correntes especiais e da fusăo;

e) relatório circunstanciado do tomador de contas;

f) parecer do chefe de Serviço a que está afeta a tomada de contas, apreciando a situaçāo do responsável.

Tomadas as contas com êsses elementos genéricos, que devem ser entendidos com as peculiaridades inerentes a cada uma das formas de tomada de contas, o processo é remetido para as Delegaçóes ou para a Diretoria de Tomada de Centas, a fim de ser submetido a julgamento. Refere-se a legislaçăo nesse caso à remessa ao Tribunal, ficando então o responsável para todos os efeitos considerados em Juízo. O prazo para o levantamento anual das contas é de seis meses, a partir do encerramento do exercício financeiro, sob as penas da lei.

\section{IV}

\section{DA INSTRUÇÃO E JULGAMENTO DOS PROCESSOS DE TOMADA DE CONTAS}

Os processos de tomada de contas, sujeitos a julgamento pelo Tribunal, devem obedecer, no que diz respeito à sua instrução, a determinados elemen. tos, tais sejam:

a) o exame das contas pelo funcionário, a quem couber por distribuiçăo o processo, no qual exporá, em informação, as conclusōes a que chegou sôbre a situaçăo do responsável e opinará pelas diligências necessárias;

b) parecer do Diretor da Tomada de Contas ou do Delegado do Tribunal sôbre a situaçāo do responsável, o qual concluirá pelo julgamento dêste, quite, em débito, em crédito, pela prescrição das contas, pelo trancamento das contas;

c) citaçăo do responsável, do seu fiador ou dos seus herdeiros para alegarem o que tiverem sôbre a situação do responsável em débito para com a Fazenda Nacional. As alegaçóes porventura apresentadas ou o recolhimenta do débito deverão ser feitcs no prazo de trinta dias, suscetível de prorrogaçã? por mais trinta, quando ocorrer justo motivo. Se, citado o responsável, não vier a defender-se, será julgado à revelia. A citaçäo será feita ou mediante cfício dirigido à repartição competente, a qual providenciará para que a determinncào seja cumprida, ou por edital, quando incerta a residência do responsável. 
Em tôrno à citação de que fala o $\S 3 .^{\circ}$ do artigo 95 , da Lei 830 , de 1949 ; a questāo nāo se apresenta de modo pacífico. Diz referido artigo:

"Será dispensada a intimação, a juízo do Ministério Público, quando êste tiver elementos para considerar o débito incobrável, ou as despesas necessárias à cobrança excederem à metade do valor do débito."

Entendo que a disposiçäo em causa dá ao representante do Ministério Público a faculdade de dispensar a cobrança, quando o exame das contas revelar que o débito é incobrável ou as despesas para sua cobrança excedem 3 metade do valor do débito. A lei năo falou que o Procurador dispensara a cobrança quando houver "julgamento em débito". Pelo contrário. Dentro da ordem processualística a citaçāo é anterior ao julgamento e a atuação do Ministério Público, nesse sentido, é, também, feita antes do julgamento. A situaçāo de débito é declarada antes do julgamento, para efeito de defesa do responsável. A citação é feita antes do julgamento pelo Tribunal. A competência, portanto, do Ministério Público é plena e năo se diga que dessa forma èle se coloca em posiçăo tal acima do Tribunal. Ao Tribunal compete julgar, e, dentro da lei, decidirá no processo em que o Procurador solicitar a dispensa da citação com fundamento naquele dispositivo, ficando a cargo daquela rutoridade demonstrar os elementos através dos quais se exterioriza o juizo de que o débito declarado é incobrável ou as despesas para sua eventual cobrança ascendem a mais da metade do seu valor. Mas repita-se, essa inter pretaçăo nāo é pacífica.

Com o pronunciamento do Ministério Público se esgota a instruçāo dos processos de tomada de contas sendo èles então distribuídos aos Auditores para serem relatados perante o Tribunal Pleno. A funçảo de relatar os processos nẩo indica apenas que o trabalho confiado aos Relatores seja aquêle de tâo sòmente repetir o que a instruçâo apresentou. Pelo contrário. O relatar prccessos envolve o estudo do processo na sua totalidade, estudo êsse isento de tôda e qualquer consideração pelas conclusões a que porventura chegar a instruçăo. A conclusāo do Auditor, de conviç̧ão intima que nâo dispensa, porém, a colaboraçāo esclarecedora e supletiva dos órgảos que integram a instrução do processo. Apresentada a proposta ante o Tribunal poderú ser acolhida ou adotada outra fórmula, a critério do Tribunal, em face das conclusōes a que porventura se chegue. Quando o processo distribuido ao Auditor importar em condenação, mesmo que o responsável haja sido citado anteriormente, o processo ficará em pauta durante o prazo de dias para defesa oral ou escrita perante o Tribunal, de onde se deflui que o responsável é suscetivel de apresentar alegaçōes na fase de instruçāo e apresentar defesa, por ocasiâo do julgamento. O prazo para permanecer o processo "em pauta" começa a ser contado a partir da data da publicaçảo no Diário Oficial.

Os processcs de tomada de contas săo julgados nas sessōes de tomada de contas, mediante a seguinte ordem de preferência:

1.") Indicaçōes e representaçōes;

2. ${ }^{\text {) }}$ Processos ou papéis distribuidos aos Ministros;

3. ${ }^{\text {a) Recursos: }}$ 
4. ${ }^{\text {a }) ~ C o m p r o v a c ̧ o ̄ e s ~ d e ~ a d i a n t a m e n t o s ; ~}$

5. ${ }^{\text {) }}$ Levantamento de fianças;

6.") Alienação administrativa de cauçōes;

7.9) Processos de tomada de contas.

Os feitos são julgados, seguidamente, de acôrdo com a ordem de antiguidare decrescente dos respectivos Relatores, sendo observada a seguinte ordem no julgamento dos processos:

$\left.1 .^{a}\right)$ relatório: sem que o Relator seja interrompido por apartes ou pedidos de informaçōes;

2.a ) discussăo: em que são pedidos os esclarecimentos necessários, por meio de informaçôes solicitadas ao Relator, ou pedindo a palavra pela ordem. Pode ser solicitado pedido de vista do processo, suspendendo-se, então, o julgamento;

3. ${ }^{\mathrm{A})}$ votação; é a fase em que o Tribunal se pronuncia através da maioria do seus membros, mediante decisăo proclamada pelo Presidente.

\section{DA SITUAÇĀO JURÍDTCA DO RESPONSÁVEL}

No que diz respeito aos processos de tomada de contas o Tribunal se pronuncia declarando o responsável quite, em débito, em crédito ou opina pela prescriçāo das contas ou pelo seu trancamento. Qualquer que seja a decisão será lavrada em Acórdăos pelo Auditor-Relator, única autoridade competente para êsse feito. Essse Acórdāo pōe têrmo ao processo de tomada de contas, salvo recurso interposto, e define a situação jurídica do responsável.

\section{CONTAS QUITES, EM CRÉDITO, EM DÉBITO}

Considera-se quite o responsável quando a seu favor nenhum saldo apresenta e contra êle não se argúi débito algum. Considera-se o responsável em crédito, quando a seu favor existir determinada importância e finalmente considera-se o responsável em débito quando o responsável fôr considerado em alcance. $\mathrm{O}$ alcance deflui como consequuência lógica da decisăo que considera o responsável em débito. Como alcance sảo considerados os seguintes:

$1^{\circ}$ ) os saldos em poder dos responsáveis;

$2^{\circ}$ ) os saldos não escriturados devidamente;

$\left.3 .^{\circ}\right)$ as despesas glosadas pelo Tribunal ou pelas Delegações;

$4 .^{\circ}$ ) as diferenças para menos verificadas na receita e para mais na despesa; espécie;

$\left.5^{\circ}\right)$ as faltas verificadas em valores, materiais e efeitos de qualquer

6. ${ }^{\circ}$ ) as diferenças verificadas a favor da Fazenda Nacional nas operaçôes de crédito e crédito dos cofres especiais;

$7^{\circ}$ ) o adiantamento cuja aplicaçâo nâo tiver sido devidamente comprovada no prazo legal; 
$8^{\circ}$ ) a importância de pagamentos feitos sem o registro do Tribunal ou suas Delegaçōes;

9. ) a responsabilidade de fundos perdidos ou furtados sem prova de fôrça maior e de haverem os responsáveis acautelados êsses fundos, de modo a excluir culpa.

\section{DOS JUROS DE MORA}

Em relação aos juros de mora é o Tribunal o único competente para conhecer dos pedidos de relevação dos juros decorrentes de alcances apurados na tomada de contas.

Os juros de mora são devidos:

a) sôbre os saldos não recolhidos; são calculados sôbre o saldo demonstrado na conta corrente desde o dia seguinte àquele em que terminou o prazo para o recolhimento, até a véspera do dia em que se tornar efetiva a entrega aos cofres públicos;

b) sôbre as percentagens perdidas pelos exatores: sâo calculados sôbre a percentagem a que o exator tiver direito e houver perdido em consequência da retenção do saldo em seu poder, além do prazo do recolhimento;

c) sôbre os alcances apurados na tomada de contas: são calculados sôbre o alcance total fixado na sentença do Tribunal de Contas do dia seguinte ao em que findou o prazo conseqüente à condenaçăo até à véspera do recolhimento.

Sôbre o total de adiantamento năo comprovado em tempo próprio ao invés de juros de mora, impōe-se a multa de $1 \%$ ao mês, calculada sôbre o total do adiantamento até a entrega da conta e restituição do saldo, salvo motivo de fôrça maior.

Quando o responsável tiver requerido a tomada de suas contas, os juros de mora sôbre nāo recolhidos só serāo cobrados, até a data da entrada do seu requerimento, se a demora fôr por culpa da repartiçáo competente para organizá-la.

\section{CONTAS PRESCRITAS. CONTAS EM ATRASO, TRANCAMENTO DAS CONTAS}

Contas prescritas são aquelas contas anteriores ao exercício de 1924, exceção feita daquelas que acusam saldos de caixa retidos em poder dos responsáveis em quantia total superior a dez cruzeiros ou quando se tratar ùnicamente de responsáveis por materiais que tenham em qualquer tempo respondido por desvio de bens sob sua guarda.

Contas em atraso sầo as contas compreendidas nos exercícios de 1924 a 1938 e săo examinadas sob o aspecto aritmético e confrontação dos documentos e observadas as seguintes condiçōes:

a) será levantada uma só conta corrente geral de caixa para todo o período da gestāo em atraso de cada responsável sendo dispensadas contas 
correntes especiais ou de valores, bem como demonstrativos analiticos de entrada e saída de material; veis;

b) são compensáveis desde logo os débitos e créditos dos responsá-

c) sòmente estão sujeitos a juros de mora os débitos resultantes de saldos retidos pelos responsáveis, contados os juros a partir da data da notificação para o seu recolhimento aos cofres públicos;

d) não são computáveis débitos ou créditos apurados até a quantia total de dez cruzeiros.

e) se pelo exame aritmético se verifica a existência de qualquer débito ou crédito superior a dez cruzeiros, será feito o exame moral das contas, isto $\varepsilon$, a legalidade da receita arrecadada e da despesa efetuada.

O trancamento das contas é determinado quando as mesmas săo consideradas iliquidáveis, em virtude dos casos de fôrça maior alegados pelo responsável, e provado ter o mesmo tomado as cautelas necessárias, seja mediante prova de fato, documental ou deduzida por justificação.

\section{DA INEXISTENACIA DE ARQUIVAMENTO EM PROCESSOS DE TOMADA DE CONTAS}

Levantadas as contas e remetidas ao Tribunal, diz a lei, o responsável desde logo se considera em juizo. Há uma responsabilidade em aberto que exige pronta đefiniçăo. Há que se estabelecer, ainda que a questāo nāo apresente pontos de vista uniforme, um julgamento sôbre o mérito da aplicação dos dinheiros despendidos. E necessário que se ponha um têrmo à situação nascida do nexo causal que existe entre o responsável e o quantitativo por êle recebido e despendido. Em última análise: é imperativo o pronunciamento do Tribunal sôbre tais contas.

$\mathrm{E}$, dentro das sentenças lavradas fala-se em quitação, débito, crédito, prescriçăo de contas, trancamento de contas. Em tôdas há o pronunciamento inexorável que define a situação jurídica do responsável perante a fazenda Nacional. Em nenhuma delas existe a cominação da ausência de julgamento a que, em último caso, se reduz o arquivamento. Desde que a lei declara o responsável em juizo reconhece implicitamente que há contas que foram tomadas e contas que devem ser julgadas. E o responsável que se encontra em crédito e que tem direito a haver o saldo a seu favor. E o responsável que se apresenta em débito, donde a necessidade de serem efetivadas as devidas providências para o recolhimento do alcance. $\mathrm{E}$ o responsável que está quite e que exige esta conclusāo the seja reconhecida mediante Acórdão e posteriormente expedida a respectiva provisăo.

O arquivamento de processos de tomadas de contas não se justifica, mesmo na hipótese de ser insuficientè a documentação apresentada, eis que, mesmo nesse caso, é facultado ao Tribunal requisitar qualquer documento, de qualquer que seja a autoridade. Não existe, portanto, mesmo nas tomadas de contas que obedeçam a rito especial essa decisão que importava na manutençāo do silêncio sôbre a situaçäo jurídica do responsável, mantendose em aberto a responsabilidade pelo manejo dos dinheiros públicos. 


\section{V \\ DOS RECURSOS EM MATÉRIA DE TOMADA DE CONTAS}

Das sentenças oriundas das decisōes do Tribunal são admitidos recursos de duas modalidades:

a) embargos;

b) revisāo, sendo de notar que tais recursos săo os únicos admitidos em virtude do exercicio de uma jurisdiçāo própria e privativa.

Os embarkos podem ser de duas espécies:

a) infringentes, nos seguintes casos: pagamento ou quitaçāo da quantia fixada como alcance.

b) de declaração: quando houver necessidade de ser sanada alguma omissâo ou esclarecido algum ponto obscuro da sentença.

O prazo para a interposição dêsse remédio jurídico é de dez dias, contados a partir da notificação da sentença ou publicação no Diário Oficial e sòmente podem ser opostos pelo responsável ou pelo representante do Ministério Público. Se rejeitados os embargos, proceder-se-á à execuçāo da sentença. Caso contrário, será o Acórdão reformado, nos têrmos do provimento dos embargos.

O recurso de revisão tem por fim a revisão do processo e do julgado e leva à suspensão da sentença. Interposto uma única vez só o pode ser pelo responsável, seus herdeiros ou fiadores e pelo representante do Ministério Público, sendo que no primeiro caso o prazo é de cinco anos, enquanto năo prescreve o seu direito contra a Fazenda Nacional, e, no segundo, enquanto não prescrever o seu direito contra o responsável e, em cinco anos, quando a decisäo fôr baseada em documento inquinado de falsidade.

O recurso de revisâo deve ter como base:

a) êrro de cálculo nas contas;

b) omissão, duplicata ou errada classificaçăo de qualquer verba ou crédito; bunal.

c) falsidade de documento em que se tenha baseado a decisăo do Tri-

Admitido o recurso, relatado por Ministro, voltará o processo à Diretoria, que o instruirá, e, após audiência do Ministério Público, o processo é distribuído ao Auditor que o relatará perante o Tribunal mantendo-se a decisāo anterior ou a reformando nos têrmos do recurso, reformando-se entäo o Acórdão, de acôrdo com a decisão proferida pelo Tribunal.

\section{DA EXECUÇĀO DE SENTENÇA}

Se decorrido o têrmo da notificação ou publicaçăo da sentença, se nesta houver o Tribunal julgado o responsável quite, em crédito ou tiver suas contas prescritas, o processo será arquivado na Diretoria depois de expedida a provisāo de quitação ao responsável. Se, porém, fôr considerado em débito, terá o responsável o prazo de trinta dias para apresentar recurso ou então recolher o débito. Denegado o recurso e não recolhido o débito proceder-se-á a alienação administrativa da caução prestada pelo responsável. 


\section{DA ALIENAÇÃo ADMINISTRATIVA DA CAUÇĀO}

A lei manda que o responsável ao tomar posse e antes de entrar em exercício de determinados cargos preste uma fiança que responda pelo exercício normal de suas funçōes. E uma garantia que se oferece à Fazenda Nacional para sustentar a regularidade de atribuiçỏes envolvendo a gestāo de bens ou dinheiros públicos. Se o responsável vier a ser considerado em débito e nâo recolher a importância considerada em alcance proceder-se-á alienação administrativa da cauçāo. Cumpre distinguir aí três situaçōes:

a) quando o responsável tiver cauçäo;

b) quando o responsável não tiver cauçẫo.

Na primeira hipótese, a alienação será requerida pelo representante do Ministério Público. Deferida a medida, será expedida ordem à repartição competente ou repartiçảo seguradora para recolher ccmo renda eventual a totalidade da caução ou parte dela para cobrir o alcance e juros de mora. Havendo saldo será o mesmo escriturado no cofre de Depósitos Públicos, à disposição do responsável.

Efetuada a alienação de cauçāo há que considerar duas hipóteses:

a) se a caução foi suficiente para cobrir o alcance, será expedida a provisão de quitação;

b) se a caução não foi suficiente, o representante do Ministério Público tomará as devidas providências para o ajuizamento, pela autoridade competente, da ação executiva.

Se o responsável nāo tiver fiança poderá ser determinado, se fồ o caso, o desconto de uma só vez dos vencimentos ou dos proventos de inativo, a par da apuração de responsabilidade pela autoridade administrativa, que deu posse sem a devida prestação de fiança. Não fica excluída, também, a hipótese de haver o seqüestro da caução ordenado pelo Tribunal a pedido do Ministério Público, quando se tratar de seguro fidelidade e a instituição seguradora năo alienar a cauçăo.

O expediente da alienaçâo da caução deverá ser concluído dentro do prazo de trinta dias, contados a partir da data do recebimento do ofício pelo Tribunal à autoridade a que couber dar cumprimento àquela decisão. Esse prazo, a juizo do Tribunal, poderá ser prorrogado por mais de trinta dias e a decisão do Tribunal terá de ser cumprida sob as penas da lei.

\section{DO EXECUTIVO FISCAL}

Concluído o expediente de alienação da cauçăo e não tendo sido a mesma suficiente para cobrir o débito, será promovida ação executiva por intermédio do Representante do Ministério Público que, para tal fim, se entenderá com os Procuradores da República, dentro de quinze dias, a partir do recebimento dos documentos. Ultrapassado êsse prazo, incorrerá o dito Procurador em crime de responsabilidade, da mesma forma que o Procurador Geral da República e o Presidente do Tribunal que, em idêntico prazo, não tomarem providências para a punição dos primeiros. Iniciado o executivo 
fiscal nenhuma intervenção tem mais o Tribunal no processo. Esgotada ficou a sua competência. Apenas ao Presidente do Tribunal deverá ser comunicado qualquer incidente que suste o andamento da execução, por parte do representante da Fazenda.

\section{VI \\ DAS ENTIDADES AUTÁRQUICAS - CONCETTO E CLASSIFICAÇĀo}

A administração, como se sabe, pratica inúmeros atos que pressupōem um complexo de organismo administrativo, todos êles com funçōes, eminentemente, de execuçāo. Tais órgảos se entendem como administraçăo direta ou centralizada e como administração indireta ou descentralizada, caracterizada, segundo MARCElo CaEtano, da seguinte forma:

"Fundamentalmente, há a considerar se determinado feixe de interêsse está confiado a uma só pessoa coletiva de Direito Público, com a faculdade de praticar atos definitivos e executórios; ou disperso por mais de uma pessoa coletiva, com autoridade para os prosseguir: no primeiro caso, temos administração centralizada (concentrada ou desconcentrada); no segundo, uma administraçāo descentralizada ou autárquica" (Manual de Direito Administrativo, $3 .^{\text {a }}$ ed., Coimbra, 1951, p. 347).

Nesse sentido, portanto, a administração direta ou centralizada, constituiu-se pelos Ministérios, Conselhos, Comissôes; a administraçāo indireta abrange as autarquias, as sociedades de economia mista e as funçōes de direito público. Além disso, há que se notar que o Poder Público acolhe, através dos serviços públicos concedidos, a colaboraçâo dos particulares, de idêntica forma que as entidades de utilidade pública e aquelas outras que o Estado auxilia e subvenciona.

Essa repartição, na vida estatal, por via indireta, fơ ocasionada pela multiplicidade de encargos que ao Estado săo hoje confiados, mercê dos inúmeros e especificos aspectos de que êste se reveste, exigindo que parte dos serviços públicos seja descentralizada: descentralizaçāo institucional ou por serviços.

Decorrentes destas premissas certos serviços se foram desintegrando parcialmente da administraçāo direta, organizando-se de acôrdo com as necessidades das tarefas a executar. Tais órgãos passam a constituir-se fora da hierarquia centralizada, porque têm personalidade e patrimônio próprios, e sua institucionalizaçāo especial visa melhor atender à conveniência $\mathrm{e}$ utilidade públicas.

A autarquia se constitui como administração indireta: é órgāo administrativo autônomo mediante orçamento próprio. A autarquia tem personalidade jurídica de direito público. A autarquia subordina-se exclusivamente ao regime legal. A autarquia exerce funçăo de Estado e está sujeita à tutela estatal. A autarquiả constitui patrimônio próprio.

Suscitando controvérsias, a Lei n. ${ }^{\circ} 830$, de 23 de setembro de 1949, conceituou como autarquia não só o serviço estatal descentralizado, com 
personalidade jurídica de direito público, custeado mediante orçamento próprio, independente do orçamento da Uniâo, mas, também, as demais pessoas jurídicas, especialmente instituidas por lei, para execuçẩo de serviços de interêsse público ou social, custeados por tributos de qualquer natureza ou por outros recursos oriundos do Tesouro Nacional. Como decorrência dêsse entendimento, adotou-se, para efeito de prestação de contas, a seguinte classificaçāo:

a) Autarquias de Assistência e Previdência Social.

b) Autarquias culturais.

c) Autarquias corporativas ou de fiscalizaçäo profissional.

d) Autarquias de exploraçăo de terras e execução de obras públicas.

e) Autarquias de exploração industrial.

f) Autarquias de economia popular, crédito e financiamento.

B) Autarquias de intervenção econômica.

Muito embora apresentando características comuns, as autarquias, que ali se enquadram possuem regime orçamentário que deve atender à finalidade para que foi criado o órgăo. Essa especificidade de funçōes, porém, năo constitui obstáculos a que sejam efetuadas tentativas para a unificação, para a padronizaçāo dêsses orçamentos, quer na sua fase de simples elaboraçāo, quer posteriormente, por ocasião da tomada de contas.

\section{PADRONIZAÇÃo DOS ORÇAMENTOS E BALANÇOS DAS AUTARQUIAS}

No tocante à institucionalizaçăo de um sistema administrativo visando à padronização dos orçamentos e balanços das autarquias, conviria salientar qque, na extinta Comissäo de Orçamento do Ministério da Fazenda, já havia sido criado o Serviço de Orçamento das Autarquias, de acôrdo com o DecretoLei' n. ${ }^{\circ}$ 5.570, de 1943 .

Em virtude đêsse diploma legal foram as autarquias obrigadas a enviar àquele Serviço, uma via de suas propostas orçamentárias e de seus balanços econômicos, financeiros e patrimoniais, a fim de que a publicação dos mesmos, em anexo respectivamente ao Orçamento Geral da Uniăo e ao Relatório da Contadoria Geral da República, só fôsse feita de acôrdo com os padrōeś estabelecidos pelo dito Serviço.

Pelo Decreto-lei n. ${ }^{\circ}$ 7.416, de 26 de março de 1945, que transformou a Comissão de Orçamento do Ministério da Fazenda em divisăo de Orçamento e Organizaçāo, integrada no Departamento Administrativo do Serviço Público, o referido Serviço, muito embora mediante regulamentaçāo passasse a ser simples Seçăo dos Orçamentos das Autarquias, permaneceu, além de outras, com as atribuiçōes indicadas de padronizar e coordenar os orçamentos e balanços das entidades autárquicas federais.

Procurando desempenhar as funçōes às quais tinha sido destinada, a Seção dos Orçamentos das Autarquias adotou desde logo as Instruçōes Provisórias sôbre a elaboração e apresentação das propostas orçamentárias, expedidas pela extinta Comissão do Orçamento, com as modificações impostas pela experiência e exigidas pela prática, que sòmente a continuidade dos serviços pode aperfeiçoar. 
Em linhas gerais, tais instruçōes, ainda hoje, persistem à efetivaçāo do disposto no Decreto-lei 5.570 , de 1943. Com o advento da Constituiçâo de 1946 e tendo em vista o disposto no artigo 73 da Lei Magna, a remessa daqueles orçanientos ao Congresso foi medida que logo se impôs. Nesse sentido - D.A.S.P., em longa Exposiçăo de Motivos ao Senhor Presidente da República, insistiu por que se procurasse cumprir a lei nos seus térmos precisos salientando a necessidade de se controlarem frontalmente os orçamentos autárquicos, da seguinte forma:

\section{"Excelentíssimo Senhor Presidente da República}

Em decorrência do que dispõe o Decreto-lei 5.570 , de 10 de junho de 1943 săo as entidades autárquicas federais obrigadas a remeter a êste Departamento, para efeito de coordenação e publicaçāo, cópia dos respectivos orçamentos ou propostas orçamentárias.

2. Relativamente ao exercício de 1948 , o prazo para remessa dos aludidos documentos sòmente se esgotará no último dia do próximo mês de setembro.

3. Sucede, entretanto, que o artigo $\mathbf{7 3}$ da Constituiçāo admite a possibilidade de serem inclúdos os orçamentos das entidades autárquicas federais no Orçamento Geral da República, achando-se, aliás, já em debate no Parlamento, algumas proposiçōes a respeito.

4. Em consequiência, se assim fôr decidido, deverá êste Departamento estar preparado para enviar tais documentos ao Legislativo, o mais ràpidamente possível, o que, lògicamente, só poderá se receber das autarquias os informes necessários e em prazo tal que lhe permita realizar o enquadramento das propostas orçamentárias aos pađrōes estatuídos.

5. Os documentos orçamentários, relativos ao corrente exercício, chegaram a êste Departamento, em sua maior parte, muitos meses após a data marcada, havendo mesmo algumas entidades que os não remeteram, apesar das reiteradas recomendaçōes dessa Presidência.

6. Désse modo, nāo se tem conseguido, nem com tolerável atraso, a observância do prazo marcado.

7. Finalmente, vale ressaltar que para a hipótese ora configurada - a de exigir do Legislativo os orçamentos das entidades autárquicas federais - já se ofereceu a êste Departamento o ensejo de submeter o assunto à atenção de V. Ex,a em sua Exposição de Motivos n. ${ }^{\circ} 236$, de 13 de fevereiro do fluente ano, quando apresentou um projeto de Circular que apenas logrou resposta de uma delas - a Estrada de Ferro Noroeste do Brasil - e nos têrmos que constam de cópia junto.

8. Eis porque se faz mister obter dessas instituiçōes, pelo menos, a estrita observaincia do prazo fixado, razăo pela qual tenho a honra de sugerir a V. Ex." a expedição de nova Circular, cujo 
projeto segue em anexo, ressaltando a necessidade de envidarem todos os esforços no sentido de que a remessa de seus orçamentos năo ultrapasse, de forma alguma, a data de 30 de setembro próximo."

Aprovada referida Exposiçāo, foi, em consequiência, expedida a Circular, na forma abaixo transcrita:

\section{"Senhor Presidente}

Havendo o Senhor Presidente da República aprovado as suas gestōes contidas na Exposição de Motivos n. ${ }^{\circ} 1.547$, de 23 do corrente mês, do Departamento Administrativo do Serviço Público, solicito a V. Ex. ${ }^{a}$ que, de forma alguma se ultrapasse o prazo para a remessa ao citado Departamento, da proposta orçamentária relativa ao exercício de 1948, da entidade sob sua direçäo. Certo de que V. Ex. ${ }^{a}$ bem compreenderá quão imperioso se faz esteja o Executivo habilitado a atender à possível solicitação do Parlamento no sentido de que the sejam fornecidas as propostas orçamentárias das entidades autárquicas federais, referentes ao próximo exercício, aproveito a oportunidade para renovar......"

Malgrado tais esforços, a verdade é que a padronizaçāo dos orçamentos autárquicos ainda se ressente de graves deficiências.

\section{DO CONTRÔLE DOS ORÇAMENTOS DAS ENTIDADES AUTÁRQUICAS}

Muito embora os esforços feitos, para resolver o problema da padronizaçâo, apenas tenham logrado solução parcial, verdade é que os Institutos e Caixas de Aposentadoria já possuem um conjunto de normas estabelecidas em alicerces estrutura; baseados em regras de ordem técnica e de ordem administrativa, acompanhadas de um Plano de Contas, o que representou, até agora, o passo mais avançado nèsse setor. De idêntica forma o contrôle a ser exercido sôbre aquêles orçamentos padece, também, de deficiências. Com razăo, afirma Trmistoches Cavalcanti que:

"não seria possivel dentro do plano atual de nossas instituiçōes autárquicas determinar, com precisão, os têrmos exatos dos sistemas de contrôle exercido pelo Estado sôbre seus atos no terreno financeiro (Principios Gerais de Direito Administrativo, - 2." ed., Freitas Bastos, Rio, p. 240).

Em apoio de tal assertiva poder-se-ia asseverar que algumas autarquias até hoje refugam qualquer tipo de contrôle; outras, admitem-no de maneira remota e, apenas algumas, se sujeitam e prestam suas contas em conformidade com o mandamento constitucional. Em seu período inicial, as autarquias sofriam apenas a supervisăo da autoridade a que estavam vinculadas, mediante a apresentaçäo de relatórios, demonstrativos de contas, balanços, etc. Tal modalidade de contrôle cedo foi julgada inoperante e, com o crescimento do número de organismos que desfrutavam de ampla autonomia 
financeira, foi exigido que as contas fôssem prestadas em bases mais claras e positivas, de tal modo que se demonstrasse a integral aplicaçăo dos recursos autárquícos, nos objetivos que nortearam a criação dos estabelecimentos páblicos personalizados.

A Constituiçāo de 1934 continha, nesse sentido, um salutar preceito, no sentido de impor-se o contrôle financeiro sôbre os serviços autônomos, pela forma prevista nas leis que os estabeleceram (artigo 101, § $3 .^{\circ}$ ), Lei n. 156 , de 24 de dezembro de 1935 (art. 35) e Decreto n. 426 , de 12 de maio de 1938 (art. 35).

A atual Constituiçāo, mercê de seu espírito democrático, na revivescêncía de dispositivos de 1934 inclui salutar preceito que consagra a jurisdiçâo do Tribunal de Contas sóbre os administradores das entidades autárquicas. Posteriormente, por fôrça da Lei n. ${ }^{\circ} 830$, de 1949, o têrmo autarquia foi conceituado de maneira ampla, o que implicou, de certa forma, na relutância de determinadas entidades em aceitar a prestaçâo de contas, sob o fundamento de que eram pessoas de direito privado. Estes fatos vieram atestar a necessidade imperiosa de instaurar-se um sistema de fiscalização da administraçáo indireta, que pudesse, de alguma forma, atingir até mesmo às sociedades de economia mista. No que tange aos vínculos que os ligam ao Estado, as autarquias brasileiras se revestem das mais variadas nuances. As autarquias culturais encontram-se ligadas à Presidência da República, ao Ministério das Relaçōes Exteriores e ao Ministro da Educação e Cultura. As autarquias corporativas são vinculadas ao Ministério da Justiça e Negócios Interiores e ao Ministério do Trabalho, Indústria e Comércio. Os serviços, ligados ao Ministério da Viaçũo e Obras Públicas ou da Justiça, encontram-se fiscalizados por Delegaçōes de Contrôle. As autarquias de intervenção econômica săo ligadas ao Ministério do Trabalho e têm seus atos aprovados por Conselhos Fiscais ou Juntas. As autarquias de crédito são supervisionadas pelo Conselho Superior das Caixas Económicas e Ministério da Fazenda. As autarquias de Previdência Social se encontram sob a jurisdiçuio do Ministério do Trabalho, através do Departamento Nacional da Previdência Social. Esse sistema não exclui, porém, outras -modalidades de fiscalização que, ocasionalmente, possam ser exercidas, tais como aquelas que se prendem à intervençâo governamental mediante Comissōes de Inquérito.

Na I Conferência de Contadores de Autarquias, reunida nesta Capital, sentindo-se a amplitude do problema, não sòmente no que se relaciona com a padronizaçăo e o contrôle dos orçamentos autárqquicos, mas também, no seu antecedente primacial, que é a conceituação do que seja autarquia, aprovaram-se as seguintes indicaçốes:

a) A Conferência deve abster-se de um pronunciamento frontal sôbre conceituaçãao e enquadramento das autarquias. Tratando-se de matéria juriđica nāo pacífica, envolvendo-se em conflito, nẩo convém a uma Conferência de Contadores decidir sôbre a mesma. A Conferência, contudo, poderá formular uma indicaçấo, sugerindo a redefiniçẩo legnl de "entidades autárquicas", consentânea com a doutrina $\mathrm{e}$ de forma a evitar as dúvidas que ora vêm ocorrendo, já mesmo sob a alçada do Judiciário; 
b) A Conferência sugere ao Govêrno a convocaçăo, em tempo oportuno, de uma nova Conferência, desta vez mais ampla, em que cada autarquia compareça por intermédio de uma Delegação composta de seu Contador Geral, de seu Consultor Jurídico e o Chefe de seus Serviços Administrativos;

c) A Conferência sugere ao Govêrno a designação de uma Comissão para elaborar o anteprojeto de um Estatuto das Autarquias.

Por outro lado o Legislativo não tem descurado do problema: a falta de contrôle e a ausência de fiscalização sôbre as autarquias ali têm sido denunciadas. Já em 1947, em projeto apresentado quando deputado, o ExPresidente da República, Sr. CAFÉ FILHo, observava:

"A precariedade do contrôle sôbre as autarquias 6 simplesmente notória. Trombeteia-se a própria imprensa aos quatro ventos e a todo instante; pode ela ser constatada pelas mais variadas maneiras; recentes debates do próprio Tribunal de Contas, em tôrno do assunto, as Circulares do Presidente da República aos administradores autárquicos, a propósito da prestação de contas àquele Tribunal, ex̃o provas insofismáveis de como vêm agindo êsses "donos de coisas alheias"; a impunidade dêles constitui prova cabal da situaçáo de irresponsabilidade moral com que se acham acobertados. Em suma, pelo menos o processo de contrôle das autarquias precisa ser melhorado. Pode mesmo ser que isso nada adiante, mas é preciso que, pelo menos, o Poder Legislativo dessa culpa fique isento.

Outros projetos versando a necessidade dêsse contrôle, de uma forma ou de cutra, foram apresentados, admitindo-se até mesmo a possibilidade de submeterem-se a essa fiscalizaçäo as sociedades de economia mista. Mas, a verdade é que nâo basta a simples imposiçāo de prestar contas. E necessário ir além para que se efetive o exame nāo sòmente no sentido do seu aspecto documental, formal, para que se possibilite um exame real, no sentido da legalidade e da moralidade dos quantitativos despendidos, em proveito da instituição.

AS TOMADAS DE CONTAS DAS ENTIDADES AUTÁRQUICAS E O TRIBUNAL DE CONTAS

Perante o Tribunal de Contas os processos de tomada de contas dos administradores das autarquias obedecem aos mesmos trâmites que os demais. Apenas diferem no tocante à apreciaçăo dos elementos considerados essenciais para que se considere regular um processo de tomada de contas. Tais elementos se encontram nas Instruçōes baixadas pelo Tribunal.

$\mathrm{Em}$ face dessas instruções os processos sẫo submetidos a estudos na Diretoria de Tomada de Contas e julgados pelo Tribunal. Tais julgamentos, porém, săo sempre precedidos de uma série interminável de diligências e pedidos de prorrogação de prazo. A imposiçăo de sançôes não tem obstado a protelação na remessa das tomadas de contas, de onde deflui uma demora, por vêzes, prolongada, no julgamento dos processos.

Os elementos necessários para o exame da tomada de contas dos administrađcres de autarquia săo arrolados em seguida. 


\section{VII}

NORMAS PARA EXAME DOS PROCESSOS DE TOMADA DE CONTAS DAS INSTITUIÇŌES DE PREVIDÊNCIA SOCIAL, NO QUE FÔR APLICÁVEL AOS DAS DEMAIS ENTIDADES AUTARQUICAS

\section{Orçamento e sua execuçăo}

a) Cópia autêntica do orçamento para o exercício a que se refere a prestação de contas, devidamente aprovado, na forma da lei;

b) cópia autêntica do ato ou deliberação que aprovou o orçamento;

c) relaçāo dos reforços, suplementaçōes ou créditos adicionais, e transferència de dotaçōes, concedidos durante o exercício, comprovadoos com cópias autênticas dos atos que os autorizaram e aprovaram;

d) indicaçăo do órgăo oficial em que houverem sido publicados os orçamentos $\mathrm{e}$ atos referidos nos ítens anteriores;

e) quadro demonstrativo da execuçăo orçamentária, por títulos da receita do orçamento aprovado, contendo a receita orçada, a arrecadada e as diferenças para mais e para menos;

f) quadro demonstrativo da execuçẩo orçamentária da despesa por subconsignação, contendo em colunas distintas: a despesa prevista no orçamento aprovado, os reforços, suplementaçōes e transferências de dotaçốes, os totais da despesa autorizada, a despesa efetivamente realizada e as diferenças para mais ou para menos entre a despesa autorizada e a realizada;

B) cópia autêntica dos atos ou deliberações que homologaram as despesas excedentes às dotaçōes.

\section{Balanços $\theta$ anexos}

a) Balanço Geral do Ativo e Passivo; e Despesa);

b) Demonstração da Conta Geral "Resultado do Exercício" (Receita

c) Conta Corrente do Responsável (Modêlo anexo);

d) Demonstrativos sintéticos das inversōes patrimoniais em imóveis e bens mobiliários (títulos, etc.) comprovados êstes últimos com as respectivas relações fornecidas pelos Bancos, quanto aos bens custodiados;

e) têrmos de conferência de valores em tesouraria e almoxarifados;

f) relação dos saldos das diversas contas bancárias comprovados com memorando dos Bancos;

B) demonstraçāo da conciliaçăo das diferenças verificadas entre os elementos oferecidos pelos Bancos e o consignado no Balanço, quanto aos bens custodiados e depósitos bancários; cício;

h) demonstração da situação dos fundos e reservas especiais no exer-

i) cópia autêntica de autorizaçóes do orgão competente para operaçốes que dependem de aprovaçăo da instância superior ao Administrador;

j) cópia autêntica do parecer do Conselho Fiscal, Conselho Deliberativo, etc., sôbre os Balanços do exercício. 


\section{Relatório do Tomador de Contas}

I - Preliminares

a) cópia do ato que motivou a tomada de contas, se houver;

b) nome do administrador responsável e data do início da gestão;

c) período das contas apreciadas;

d) ementa da legislação específica da instituiçāo;

e) resultado do exame geral levado a efeito no sistema contábil, no tocante às formalidades extrínsecas e intrínsecas dos elementos examinados;

f) apreciaçāo quanto à observância, quer na previsăo, quer na execuçāo, do plano de contas oficialmente determinado (apresentação de orçamento econômico-financeiro, de administraçâo e de inversōes e balanços) e da nomenclatura das contas patrimoniais.

\section{II - Da receita}

a) Apreciaçắo sôbre a observância das normas legais relativamente à apuraçāo, classificação e recolhimento da receita;

b) apreciação sôbre o exame da execução orçamentária da receita;

c) conclusőes sôbre o exame detalhado de tôdas as parcelas da Receita, tendo em vista os itens anteriores;

\section{III - Da Despesa}

a) apreciaçâo sôbre a observância, em geral, das normas legais vigentes na realizaçāo da Despesa e especialmente:

1.a) sôbre o exame da documentaçāo comprobatória da despesa, quanto aos aspectos legal e formal, inclusive sôbre a obediência à Lei do Sêlo;

2.a) sôbre as despesas excedentes das dotaçōes orçamentárias e dos créditos adicionais, apreciando a justificativa apresentada a respeito pela administraçäo da entidade;

b) conclusão sôbre o resultado do exame efetuado, apontando os casos de despesas irregulares, se houver.

\section{IV - Do Patrimônio}

Relativamente às contas patrimoniais, além de sucinta referência à subsistência do ativo e procedência do passivo, considerados os grupos gerais de contas, deverá constar do relatório do tomador de contas apreciaçāo sôbre o resultado do exame:

a) das mutaçōes patrimoniais verificadas no ativo imobiliário, especialmente quanto às operaçōes imobiliárias inclusive no que disser respeito ao custo da anterior e da última aquisiçāo;

b) das disponibilidades (Caixas e Bancos); 
c) das contas que compōem o ativo transitório, considerado o grupo de devedores diversos e nestes compreendidos os responsáveis por alcances, desvios de bens e prejuizos a amortizar;

d) das exigibilidades reais;

e) do patrimônio líquido, representado pelos fundos, de garantia e reservas diversas;

f) constará ainda do relatório apreciação sôbre a exatidão dos demonstrativos sintéticos ou anexos de balanços, em face dos inventários analíticos arquivados na instituiçăo e que não acompanham o processo.

\section{V - Conclusão}

O relatório concluirá pela regularidade ou nāo das contas e pela situação do responsável, nos têrmos do artigo, 18 , alínea "i" do ato $\mathrm{n}^{\circ} \mathrm{I}$.

\section{Parecer}

O parecer deverá ser conclusivo no sentido da aprovação ou não das contas nos têrmos do artigo 19 , alínea " $\mathrm{f}$ " do ato $\mathrm{n} .1$.

Essas Instruçōes terão a sua vigência limitada à expedição das Normas Reguladoras estipuladas segundo o artigo 139, parágrafo único, da Lei n. ${ }^{\circ} 830$ de 1949:

- "O Tribunal de Contas expedirá instruçónes sôbre a organizaçăo dos processos para julgamento das contas dos administradores das entidades autárquicas, de modo a atender às suas peculiaridades."

\section{LEGISLAÇÃO}

Código de Contabilidade.

Regulamento Geral de Contabilidade Pública.

Lei n. 830 , de 23-9-1949.

Ato n. 1 do Tribunal de Contas. 